\title{
MECHANICAL PROPERTIES OF AN AUSTEMPERED HIGH CARBON, HIGH SILICON AND HIGH MANGANESE STEEL
}

\section{SUSIL K. PUTATUNDA*}

\section{*Professor, Department of Chemical Engineering and Materials Science, Wayne State University, Detroit, Michigan 48202, USA}

In recent years there has been a significant interest in Austempered Ductile Cast Iron (ADI) as an engineering material. When ductile cast iron is austempered in the temperature range of $260^{\circ}-400^{\circ} \mathrm{C}$, it produces an ausferrite microstructure (mixture of bainitic ferrite and high carbon austenite). This unique microstructure provides many excellent properties in ADI, such as high strength with good ductility, good fatigue strength, fracture toughness and wear resistance. While ADI has excellent mechanical properties, its Young's modulus is approximately (20\%) lower than steel. Therefore the thin components made with ADI have a tendency to bend in service.

Because of this limitation of ADI, there has been a growing interest in the austempered cast steels as structural materials. Conventional cast steels lack the presence of graphite nodules because of lower silicon content as well as the absence of magnesium or cerium as nodularizers. Moreover, even though the conventional cast steels has higher Young's modulus than ADI, they also have poor castability and machinability. However, if cast steels can be made with increased silicon content (in excess of $2.00 \%$ ) and with magnesium or cerium as nodularizers, then carbon will exist in the form of graphite nodules in the matrix. On austempering such a spherodized graphite cast steel, a similar microstructure consisting of bainitic ferrite and high carbon austenite (as in case of ADI) should be obtained. With a similar microstructure to ADI, these spherodized graphite cast steels are expected to provide excellent mechanical properties and fracture toughness.

In this investigation, a new high carbon (1.0\%) high silicon (3.00\%) and high manganese (2.00\%) spherodized graphite cast steel has been developed. The influence of austempering process on the microstructure and mechanical properties of this steel was examined. The influence of austempering process on the plane strain fracture toughness of this steel was also studied. The test results show that by using a suitable austempering process it is possible to produce more than $80 \%$ austenite in the matrix. Figure1 shows a typical microstructure produced in this steel after austenitizing at $954^{\circ} \mathrm{C}$ for 2 hours and austempering at $316^{\circ} \mathrm{C}$ for $6 \mathrm{hrs}$. Figure 2 shows the effect of austenitizing temperature on volume fraction of austenite. The volume fraction of the austenite was found to increase with increase in austenitizing temperature. Presence of a large percentage of austenite (in excess of 80\%) in the matrix made the steel almost non-magnetic. Austempering has resulted in a significant improvement in mechanical properties as well as the fracture toughness of the material. The yield and tensile strength of the material decreased with the increase in austenitizing temperature (Figure 3). Figure 4 shows the influence of austenitizing temperature on fracture toughness of the material. The plane strain fracture toughness was found to decrease with the increase in austenitizing temperature Potential application of this steel are in automotive, air craft, and naval structural components. 

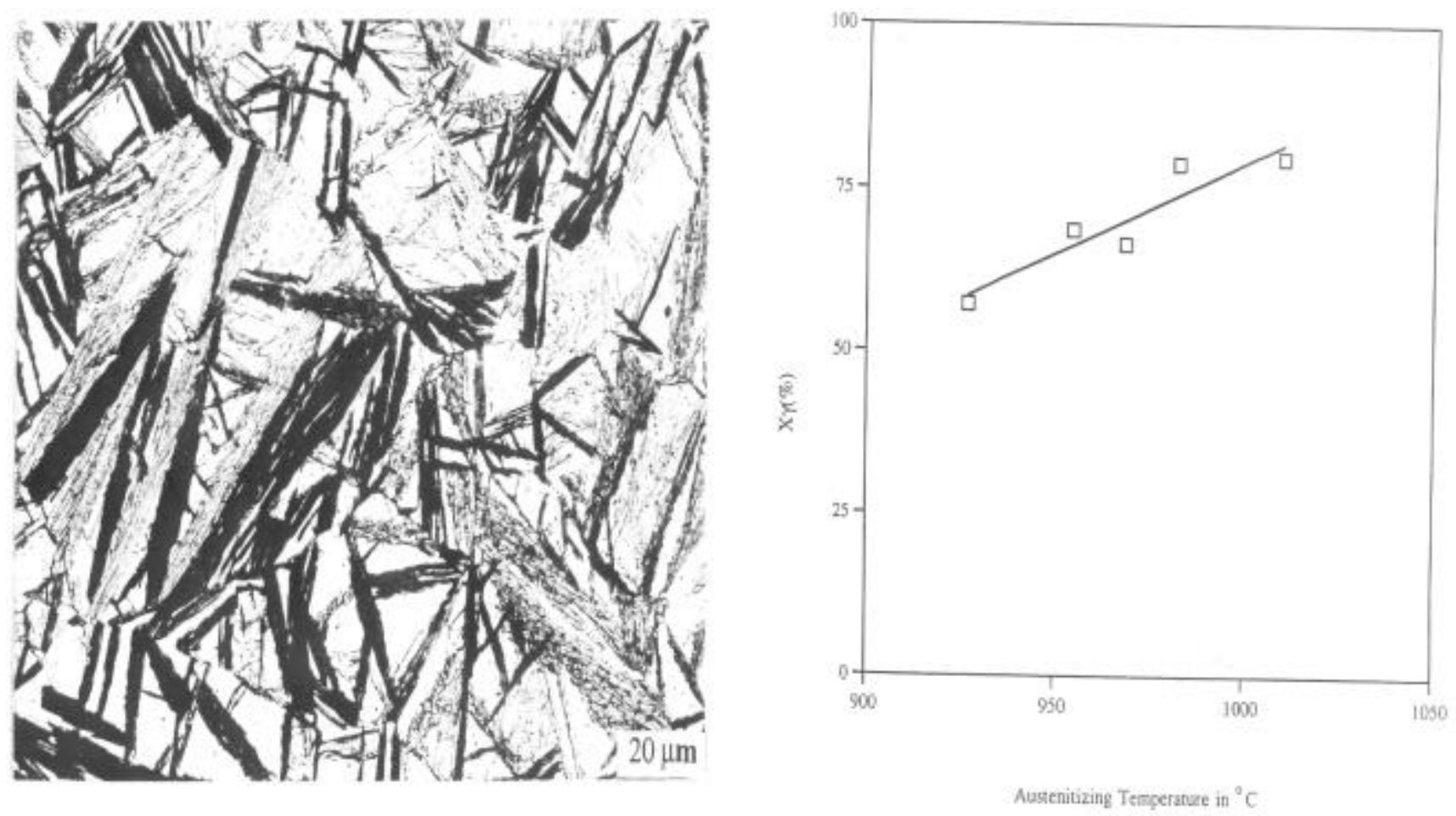

Figure 1: Microstructure of the Material. Austenitized at $954^{\circ} \mathrm{C}$ for $2 \mathrm{hrs}$.

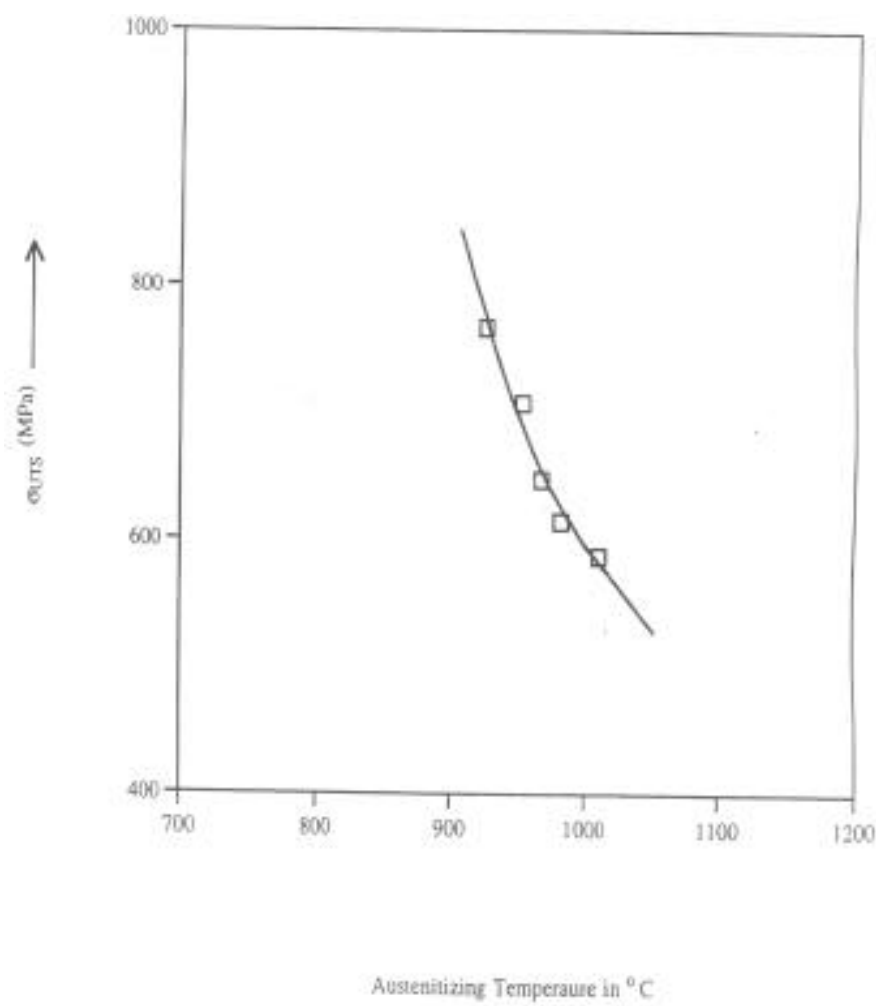

Figure 3: Influence of Austenitizing Temperature on Tensile Strength
Figure 2: Influence of Austenitizing Temperature on Volume Fracture of Austenite.

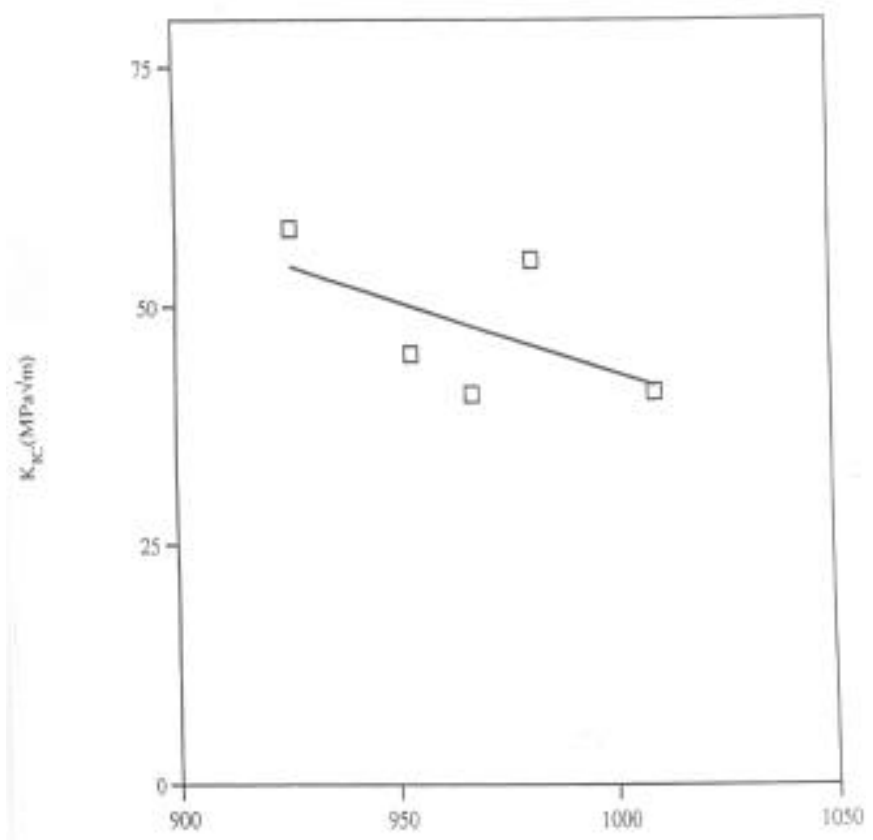

Anstenitizing Tempersoure in ${ }^{2} \mathrm{C}$
Figure 4: Influence of Austenitizing Temperature on Fracture Toughness. 